\title{
From Constitutional Volatility to Constitutional Stability: Any Chance to Reconcile Constitutionalism and Power Struggle in Ukraine?
}

\author{
Od nieprzewidywalności konstytucyjnej \\ po konstytucyjną stabilność: \\ Czy istnieje szansa na pogodzenie konstytucyjności \\ i walki o władzę w Ukrainie?
}

\section{- Abstrakt •}

Artykuł zajmuje się problematyką trwającej obecnie transformacji konstytucyjnej, która została odnowiona w trakcie rewolucji na Majdanie w latach 2013-2014. Transformacja konstytucyjna jest w coraz większym stopniu widziana jako rozwiązanie największego zdaje się kryzysu politycznego w dziejach kraju oraz jako sposób na zapewnienie długoterminowej stabilizacji ukraińskiego porządku konstytucyjnego oraz rozwoju demokracji. Artykuł rzuca światło na szereg przyczyn stojących za trwającą obecnie reformą konstytucyjną na szerszym tle uprzedniej instrumentalizacji polityki konstytucyjnej oraz niestabilności procesu konstytucyjnego. Porównano porządek konstytucyjny przed i po rewolucji (system prezydencko-parlamentarny wobec systemu parlamentarno-prezydenckiego) oraz przeanalizowano konsekwencje powrotu do systemu z dominującą rolą parlamentu. Na tle nieukończonej reformy konstytucyjnej w artykule wysunięto tezę o dalszej "parlamentaryzacji”" sys-

\section{- Abstract •}

This article addresses the problem of the ongoing constitutional transition in Ukraine that has been revived by the Maidan revolution of 2013-2014. The constitutional transition is increasingly seen as being key for solving what is apparently the greatest political crisis in the country's history, for providing long-term stabilization of Ukraine's constitutional order and ensuring democratic development. The article sheds light on a series of revolutionary causes of the current constitutional reform, against a broader context of preceding instrumentalization of constitutional politics and volatility of the constitutional process. Pre-revolutionary (presidential-parliamentary) and post-revolutionary (parliamentary-presidential) constitutional settings are compared, whilst the ramifications of re-transition to parliament-dominated rule are also scrutinized. Finally, against the backdrop of an unfinished constitutional reform, the argument developed in the 
temu konstytucyjnego na Ukrainie jako zarówno pożądanego oraz koniecznego rozwoju wypadków dla ustabilizowania społeczno-politycznego oraz konstytucyjnego porządku w kraju.

Słowa kluczowe: Ukraina, transformacja konstytucyjna w 2014, konstytucjonalizm, Euromajdan, instrumentalizacja procesu konstytucyjnego, system prezydencki, system semiprezydencki article envisions further "parliamentarization" of the constitutional setting of Ukraine as both a desirable and necessary development to stabilize social-political and constitutional orders of the county.

Keywords: Ukraine, 2014 constitutional transition, constitutionalism, Euro revolution, instrumentalization of the constitutional process, parliamentarianism, semi-presidentialism

\section{Introduction:}

\section{The Instrumentalization of the Constitutional Process in Ukraine and the Constitutional Volatility Legacy}

The most recurring problem, which complicates the constitutional process in Ukraine since independence, is a "privatization" and instrumentalization of the constitutional development. Right after coming to power, political elites strive to adjust the basic constitutional norms in a way providing them broader scope of authority and, respectively, better control of the oppositional powers. As Petro O. Dobrodumov reasonably contends, "nowadays, constitutionalism is a genuinely private resource which is used by distinct political forces in order to increase their influence on power institutions, whereby the law [the rule of law] presents a bargaining chip in such a battle for power" (Аобродумов, 2009, p. 27). As such, the 2010 constitutional retrograde also manifested an instrumentalized change of constitutional politics by the new president's governmental and parliamentary team according to their priorities and interests. Back in 2010, Sergey Borisov envisioned quite judiciously that "if the president or representatives of his team lose power at some point, the constitution will not be a sacred cow then either, and new Viktors will be able to complete the picture" (Borisov, 2010)1.

${ }^{1}$ As carefully noted by Yuriy Matsiyevsky, the process of "privatization" and instrumentalization of the country's Constitution is rooted in a so-called "institutional trap", when the power holders of every political regime in Ukraine since 2004 would not accept the pre-established "rules of the game" and thus seek to design a more favourable for them matrix of institutional relationships and informal rules (with patronage and clientelism dominating such a "governmental" system-building), as well as they would seek to selectively apply the principles of the rule of law and justice. All that is deemed to lead, according to Yuriy Matsiyevsky, to a revert constitutional process, a reiterated "involution of constitutionalism", rather than to a genuine revolution in constitutional affairs, see: Мацієвський (2011, p. 51). For a more detailed analysis of the "institutional trap" fallacy, seе: Мацієвський (2015). 
Positioning it definitely beyond the sancta sanctorum line, Natalia Chaban and Vlad Vernygora go even further in their discourse analysis of media perceptions in respect to the constitutional process in Ukraine and depict it as a "war" (Chaban,Vernygora, 2010, p. 233). This war-like rhetoric - embraced in the respective designation of such a constitutional development - revolves, according to the authors, around the discourse of the constitutional process since 1996. The latter is structured basically by the following notions: "chronicle of non-stop conflicts", "fight", "struggle", rules imposed by a "winning side on a losing side", "a fortified wall" the winning faction would enjoy following constitutional changes according to its interests, Ukrainian political rivals turning into "uncompromized opponents" and "party soldiers" in "parliamentary ranks" conducting the "war of zombies", etc. (Chaban, Vernygora, 2010, p. 237).

Along with the definition of the process as a "war", deficiencies of the constitutional development in Ukraine were further revealed via constructed discourses of the constitutional process as a "game" (Chaban, Vernygora, 2010, p. 237-238), "crime" (Chaban, Vernygora, 2010, p. 238-239), "illness" (Chaban, Vernygora, 2010, p. 239-240), and so forth. It means that the process was (and probably still is) conceived as everything but a constructive state-society dialogue in terms of elaborating sustainable and all-encompassing foundational features of both the current and a prospective constitutional order in Ukraine.

Following the assertive wave of the Maidan revolution that brought to the surface of necessary changes in the country the constitutional agenda ${ }^{2}$, such as "privatization" and instrumentalization of the constitutional process was to be observed anew. It became well visible through the struggle between the oppositional (till mid-February 2014) forces in Ukraine themselves. Obviously, the visions of a future constitutional order of Ukraine cast by the oppositional forces differed precisely because of their particularistic political ambitions, agendas and fears. As a result, each of them was trying to streamline the future social and political system in a way that would provide them with more relative advantages and ensure at least some prospects for maintaining their positions in national grand politics. As revealed (through the leaked draft of constitutional amendments by "Batkivshchyna" and "UDAR"; Найєм, 2014)33, for some political forces these perspectives have been implied in a parliamentary republic, for others - in a presidential government. Therefore, the range of lobbied models for constitu-

2 On the Maidan's constitutional agenda, see: Tyushka (2014); Zelinska (2015).

3 On constitutional amendments as offered by "UDAR", see: Войтенко (2014). On draft constitution developed by the VO "Svoboda" see: Національна Конституція (Проект ВО “Свобода", 2007). 
tional transition has been broad and divergent, which contributed to everything but the unity of then-oppositional political forces (Olszański, 2014). By casting a careful look at the options, tabled by the three opposition parties in mid-February 2014, it becomes quite clear that:

- The All-Ukrainian "Batkivshchyna" Union advocated a weak semi-presidentialism (or semi-parliamentarianism, as coined in Ukrainian political discourse) with gradual transition to a classical parliamentary government, which implied the dramatic expansion of the powers enjoyed by the Verkhovna Rada;

- The "UDAR" faction promoted a strong semi-presidentialism (or semi-presidentialism in Ukrainian political discourse), which implied even further expansion of presidential powers and the simultaneous widening of the scope of authority enjoyed by the Cabinet of Ministers;

- The All-Ukrainian "Svoboda" Union went as far as to suggest the further deepening of the tradition of presidential rule in Ukraine and, in principle, to promote the classical model of full presidentialism.

Hence, disunity had been the only thing that united then-oppositional forces in their efforts to design a constitutional reform.

Significantly, all the manifold efforts of numerous stakeholders from both the ruling and oppositional political camps, as well as organized civil society, occurred under the general label of a "return to the constitutional order of 2004", which indeed provided a surplus of legitimacy to the process. It should be emphasized, however, that several different versions of transition to the social and political order established by the amended Constitution of 2004 were tabled, including a number of contrasting and extreme options - from transition to classical parliamentarianism to an even greater strengthening of presidentialism. The latter, offered by the All-Ukrainian "Svoboda" Union, was obviously quite contrary to what had been demanded by the Maidan revolutionary movement in Ukraine, but quite in line with their even then anticipated poor election results ${ }^{4}$.

${ }^{4}$ To a large extent, such an advocacy of presidential government on the part of the All-Ukrainian "Svoboda" Union had been allegedly driven by the party's fears with regard to then-anticipated early parliamentary elections. As shown by the early parliamentary election held on 26 October 2014 , the party did not even manage to surpass the $5 \%$ threshold for the party-list vote. 


\section{The Constitutional (Re-)Transition of 2014 and its Interim Consequences}

Further struggling over the "right" mode of constitutional re-transition, against the backdrop of the ongoing revolution and external aggression, could have only deepened the crisis, mitigated the results so far achieved in terms of de-legitimation of then-ruling authorities, just as it could have contributed to a long-lasting constitutional volatility in Ukraine. Following a short but eventful period of euphoria that the new "agents" of constitutional reform, basically the three opposition parties, translated into their distinct visions of the country's future constitutional setting, a compromise was reached to disregard all of them. To confirm this, on 3 February 2014, in the name of the united opposition, the All-Ukrainian "Batkivshchyna" ("Motherland") Union tabled a constitutional bill in the Verkhovna Rada, which stipulated a return to the constitutional order of 2004 in its genuine form. One has to admit though that the process leading to this compromise proceeded rather feverishly and thus was not devoid of its own legal pitfalls and deficiencies.

Eventually, on 21 February 2014, the Verkhovna Rada of Ukraine adopted Law No. 742-VII On Restoration of Certain Provisions of the Constitution of Ukraine 5 . Given President Yanukovych's failure to sign the bill, this law was supplemented with a parliamentary resolution enacting the amendments to the Constitution and the restoration of the wording of the text of 8 December 2004. The resolution also took into account the changes made in 2011 (Law No. 2952-VI') and 2013 (Law No. 586-VII ${ }^{7}$ ). Following the publication of the law in the official journal on 1 March 2014, the constitutional order of 2004 was restored. It has been in force in Ukraine since 2 March 2014.

5 Закон України “Про відновлення дії окремих положень Конституції України”. No. 742-VII of 21 February 2014. Retrieved from: http://zakon3.rada.gov.ua/laws/show/742-18. For an insightful analysis of the 2014 constitutional process and its legality, see, for instance: Речицький (2015).

6 Закон України "Про внесення змін до Конститущї України щодо проведення чергових виборів народних депутатів України, Президента України, депутатів Верховної Ради Автономної Республіки Крим, місиевих рад та сільських, селищних, міських голів" [Law of Ukraine "On Amendments to the Constitution of Ukraine as regards Ordinary Elections of Peoples' Deputies of Ukraine, President of Ukraine, Peoples' Deputies in the Supreme Council of the Autonomous Republic of Crimea, Local Councils, and Rural, Country and Municipal Mayors"]. No. 2952-VI of 1 February 2011. Retrieved from: http://zakon3.rada.gov.ua/laws/show/2952-17.

7 Закон України "Про внесення змін до статті 98 Конституцї України" [Law of Ukraine "On Amendments to the Article 98 of the Constitution of Ukraine"]. No. 586-VII of 19 September 2013. Retrieved from: http://zakon3.rada.gov.ua/laws/show/586-18. 
Accordingly, several crucial adjustments have been made in order to return to a parliamentary-presidential form of government in Ukraine, which has considerably widened the scope of power granted to the Parliament, while at the same time constraining the presidential powers. Additionally, a stronger and more independent Prime Minister has enhanced the system of checks and balances under the renewed constitutional order. For instance, the Prime Minister is now the ex officio chief executive, but this excludes authority over ministries of defence and foreign affairs, as well as the security service, which remain the responsibility of the President. Parliamentary powers have been considerably extended with respect to controlling the Government (ministers, except for the aforementioned, are now subordinated to a parliamentary majority) and the President (the Parliament can overrule a presidential veto; laws enter into force upon their signature by the speaker of the Parliament). Under the current Constitution, the parliamentary speaker becomes acting president in case of the President's death, resignation or impeachment. The prosecutor general, who plays a very important role in the country's justice system, will once again be appointed and dismissed by a parliamentary majority.

Changes were also implied for the Ukrainian legislation deemed to have been illegally adopted within 2010-2011, which amounts to some 80 legal acts that empowered the President with superfluous authorities. These were to be abolished in a five-day term. Moreover, the necessary operational changes were introduced into the rules of procedure in the Ukrainian Parliament so that the Verkhovna Rada could acquire legal opportunities to adopt the former practice of forming a coalition composed of both parliamentary factions as a whole, and individual members of the parliament in particular. This helped overcome the anticipated deadlocks in the functioning of the seventh Ukrainian Parliament, which - according to the decision of the newly elected President Petro Poroshenko - was only recently dissolved and succeeded, on 26 October 2014, by the earlier elected eighth Parliament.

Despite all essential innovations, the constitutional transition in Ukraine is not yet complete. The return to the 2004 version of the Constitution should be regarded as a temporary constitutional settlement, yet it does not correspond with current demands for constitutional development in the country and has previously been a matter of concern for the Venice Commission (Venice Commission, 2010) ${ }^{8}$. While substantially critiquing the 1996 constitutional setting in Ukraine?,

8 See also: Савчин (2009, p. 113-120); Кравчук (2014).

9 See, for instance: Elgie (1999, p. 278-279); Protsyk (2003, p. 1077-1095); Christensen, Rakhimkulov, and Wise (2005, p. 207-230). 
the international political scholarship has also been quite outspoken in criticizing the 2004-type constitutional order ${ }^{10}$. As the Venice Commission resolutely maintained in its assessment of the constitutional engineering in Ukraine following the 2004 reform: although the 2004-type constitutional order offers "increasing parliamentary features of the political system", such constitutional amendments, however, "do not yet fully allow the aim of the constitutional reform of establishing a balanced and functional system of government to be attained" (Venice Commission, 2005). Hence, the need for a "2004 plus" Constitution is more than apparent - it is, in fact, pressing. This also has been recognised by the newly formed parliamentary coalition who, in their coalition agreement concluded on 21 November 2014, define further constitutional reform as one of their priorities for the 2014-2019 legislature.

Finally, under the conditions of the recently occurred transition of power in Ukraine, it is absolutely vital that the constitutional process is not paralyzed by the current piecemeal reforms. The comprehensive constitutional transition hoped-for in the country must be accomplished for the vicious circle of "revolution-constitution-revolution" to be broken at last, and to ensure that revolutionary constitutionalism does not become the permanent "form" of the constitutional process in Ukraine for decades to come.

\section{Beyond 2014: In Search for Constitutional Stability}

As emphasized above, in no way should the return of the 2004 version of the Constitution be misconceived as an accomplished act of the 2014 constitutional reform in Ukraine. Moreover, the 2004 reform itself had not been completed so that the pitfalls of politicizing constitutional change remain increasingly high. As Artem Filipenko put it:

"There is no question that the 2004 constitutional reform was not completed. Even the method of conducting it created a regime of semi-legitimacy in the country. Obviously, the reform should have been continued, expanding the powers of local self-government and reducing the functions of the local state administrations. But this did not happen, primarily because the initiators of the constitutional reform, no matter who it was - Yushchenko, Tymoshenko, or the Party of Regions - were trying to carry out the reform not in order to increase the effec-

10 See for instance: D’Anieri (2007, p. 38-39); Boban (2007, p. 163-169); Колодій (2014). 
tiveness of the governance mechanism, but to obtain the maximum preferences of power for their own dear selves" (Filipenko, 2011, p. 74).

That being said, one would reasonably assume that the constitutional volatility will persist as long as the constitutional process is instrumentalized to balance and, respectively, counterbalance changes in power on the Ukraine's political stage. Although to a distinct extent, the constitutional engineering as per both the 1996 and 2004 versions entailed a political-legal setting, which explicitly provided for exhibited competitive and adversarial relations between the president and the parliament as well as between the dominant and minority blocks in the Ukrainian legislature. As a result, this clashing potential has "periodically led to attempts by one branch to eliminate the other by attempting to alter the country's constitution", whereas the "[i] ssues of democratic representation and policy reform have often been subordinated to a fundamental struggle for power" (Christensen, Rakhimkulov, Wise, 2005, p. 211). In his analysis of actors involved in the constitutional process, their strategies and the actual power balance as premises for constitutional reforms, Serhiy Kudelia (2013, p. 151-178) demonstrates, in a sophisticated way, how changes in the power balance between elite actors and the variation of their time horizons affect the probability of consensual constitutional politics as well as the choice for the form of the government itself.

Eventually, Ukraine's contemporary constitutional process can be considered against the context of balancing between a "natural state" and "open access order", as coined by Douglass C. North, John J. Wallis and Barry R. Weingast (North, Wallis, Weingast, 2009). As such, it features - in the first case - the manipulation of laws and rules, including constitutional norms, in order to achieve advantages over political rivals. For an "open access order" instead, a distinctive sustainability and rationality of the rules of this political "game" is typical, and these rules would be of fundamental significance for all the stakeholders, thus presenting a greater value than the potential winning options.

Such a persisting "in-betweenness" of the Ukrainian constitutional order and the resulting tendency for political elites to instrumentalize constitutional politics is, therefore, hardly surprising. That being said, the state of permanent constitutional volatility (no matter how paradoxical it may appear) appears to have embodied a tribute to unfinished constitutional reforms. Moreover, from a wider comparative perspective, it has been revealed by the constitutionalist scholarship that on average a constitution rarely survives for more than two decades (Elkins, Ginsburg, Melton, 2009, p. 137). In countries with frequent regime shifts (between authoritarianism, protoauthoritarianism, and democracy), such volatility is especially common. In Ukraine, the constitution's survival shrunk to nearly four 
years, with eight years being the longest constitutional endurance term within the period of 1996-2004.

Therefore, in order to prevent any "constitutional rollbacks" of this kind in the future and stabilize the constitutional order in Ukraine, any halfway constitutional reforms should be excluded from current constitutional politics. They have to be bound, in addition, to a new social contract so that not only the political elites but also citizens themselves would have a say in envisioning and anchoring the country's emerging constitutional order.

Further changes to the currently revived 2004 constitutional setting in Ukraine are to a larger extent needed because the order itself is quasi-subjected to a unified European democratic space and thus "shaping of new system of societal relations, transformation of foundational values [...] and institutionalization" (Бєлов, 2013, p. 92) are unavoidable.

On the other hand, a greater degree of "constitutional security" is required to secure Ukraine's European integration agenda and the feasibility of the policies implementing this course of the state's foreign policy. As thoroughly argued by Yuriy O. Voloshyn: "Yet back in the early years of independence, the Ukrainian state has defined as its strategic goal gradual integration with the European Union. Over a lengthy implementation period of European integration politics, [...] Ukraine has failed, however, to move closer to this goal [...] so that now, in order to achieve that 'European goal' it has to create an image of a stable state, whereas the niveau of its legal and political culture shall now prove Ukraine's belongingness to the united European community, including the ability of the Ukrainian constitutional legal doctrine to secure the processes of further integration of Ukraine to the European Union” (Вомошин, 2010, p. 5) ${ }^{11}$.

Ultimately, a "2004 plus" constitution is "an opportunity for Ukraine to establish an EU-like judiciary in the Basic Law of Ukraine" (Kirsch, 2014). This would be an important step to bringing about feasible effects for Ukraine's European integration politics under the newly signed EU-Ukraine Association Agreement ${ }^{12}$

${ }^{11}$ Albert Yezerov defines "constitutional security" as a crucial structural element of Ukraine's national security system that, in fact, entails the ability of distinct subjects of constitutional-legal relationships within the state to prevent and withstand constitutional conflicts that are fraught with significant implications for both internal and external security, see: Єзеров (2013, p. 120). See also the author's earlier take on the problem: Єзеров (2011, p. 76-84).

${ }_{12}$ Association Agreement between the European Union and the European Atomic Energy Community and Their Member States, of the One Part, and Ukraine, of the Other Part. Retrieved from: http://eeas.europa.eu/ukraine/assoagreement/assoagreement-2013_en.htm. The "political part" of the EU-Ukraine Association Agreement (Preamble, Titles I-III and VII) was signed in Brussels on 21 March 2014, the "economic part" of the agreement was signed on 27 June 2014. 
that explicitly obliges the country to approximate with the Union's standards in terms of justice, freedom and security (as stipulated in the Title III of the Association Agreement $)^{13}$.

Designing such a "2004 plus" constitutional order will certainly involve a substantial degree of constitutional experimentalism and thus will search for seminal constitutional hybrids reaching from state orders that feature a strong presidency along with a strong parliamentary system or presidialisation of the prime minister's office up to orders that establish classical parliamentarianism. The latter may well include the transition to bicameralism (a classical institutional bicameralism or a rather informal bicameralism, which has already been de facto practiced in the Ukrainian political system due to a mixed election system in the past). In essence, constitutional experimentalism would be basically about "searching for solutions to the contradictions as laid down inter alia by both the Constitution in the version of 1996 and the 2004 version of the Constitution [...], but also about mitigation of negative effects of the practiced semi-presidentialism which are particularly apparent in terms of the weak party system [in Ukraine]" (Фісун, 2011, p. 51).

Along with the incompleteness of previous constitutional reforms, the "incompleteness of the state-building project itself, just as of the process of national self-determination surmounting it" (Розумний, 2013), points towards the need to search for new constitutional formulas in Ukraine. These should allow bridging the gap between the officially anchored norms and socio-political practices, which are now occupied by legal uncertainty and casuistry, manipulative political technologies, common-sense populism and corruption against the background of a socially-predicated search for new national "contents", widely acceptable norms and rules as well as ways to secure the foundations of a feasible statehood in Ukraine.

The search for a balanced and sustainable constitutional formula is significantly complicated by Ukraine's peculiar social and political cleavages. These result from specifics of Ukraine's statehood as a state-nation (or at its best - a nascent nation-state; Stepan, Linz, Yadav, 2011, p. 173-200) rather than a shaped nation-state (Rejai, Enloe, 1969, p. 143), yet it consists of several socio-cultural entities, which were previously parts of different imperial projects, that gained momentum for their cultural integration under the impetus of political unification. This implies for Ukrainian politics everything but easy coalition-making and just representative democracy in practice, since winners and losers gain a virtually equal level of people's support, and thus it drives to a constitutional god-forsaken place and/or political stalemate. To illustrate this, the last presidential elections in Ukraine held

${ }^{13}$ For more on this see: Tyushka (2015, p. 56-72). 
in January-February 2010 resulted in the victory of president Viktor Yanukovch with only $48.95 \%$ against $45.47 \%$ gained by his political opponent Yulia Tymoshenko; the last parliamentary elections held in 2012 reflected a similar situation, with $30 \%$ of the people's votes cast for the Party of Regions and $25.54 \%$ votes received by the All-Ukrainian Union "Batkivshchyna". Quite "naturally", therefore, an exit from stalemate situations of this kind was seen in paraconstitutional practices. If one considers landmark periods of contemporary Ukrainian political history, it becomes apparent that the political machinery resumed its operability only when the departure from formal constitutional norms took place - be it the very same moment of the adoption of the Ukrainian Constitution in 1996, the 2004 presidential elections, 2010 coalition-making after the next presidential elections or 2014 re-coalitioning, extraordinary presidential elections, and constitutional re-transition.

Hence, in order to preclude future stalemate that is pre-conditioned by the very constitutional settlement, to avoid manipulation and instrumentalization of the "long-suffering constitution" (to borrow the Artem Filipenko's wording; 2011, p. 74), it is necessary to accomplish a determined and comprehensive constitutional transition in Ukraine. Subsequent institutional re-engineering of the country's political system in a way allowing it to work for solutions and not further production of constitutional stalemates has to finalize the process.

\section{Conclusions}

Constitutional choices are significant - both in terms of their form and substance. What is even more important, "such choices may be less in getting the best alternatives under the circumstances than in avoiding the worse consequence one can imagine", as astutely put by Kim Lane Scheppele (2003, p. 298). This especially proves true in the context of Ukrainian constitutional choices and processes undertaken over the last two decades.

With new authorities established first on interim terms and, in fact, on the basis of the re-established parliamentary-presidential constitutional order, the constitutional process was given a new quality and dimension. Despite a set of indeed essential innovations that established a mode of government with considerably weaker presidential powers, the constitutional transition in Ukraine should not be regarded yet as eventually settled. The return to the 2004 version of the Constitution represents a temporary constitutional settlement, since it does not correspond with current demands for constitutional development in the country and has even 
before raised concerns of the Venice Commission. Both the constitutional volatility as an expression of the easily instrumentalizable constitutional process together with the distinct socio-political crises of the past two decades have amply shown that the Ukrainian Constitution, whether in its 1996 or amended 2004 version, needs a profound and comprehensive revision in order to move on from the instability that has considerably plagued it by now. It is thus the task of the newly established constitutional powers of Ukraine to further continue the constitutional process. As manifested by the political programmes of the new Ukrainian Presient Poroshenko and the recently formed coalition within the eighth Ukrainian Parliament, constitutional reform remains a priority in the country's development strategy.

A "2004 plus" version of the constitutional setting for Ukraine, as herewith anticipated, shall not only mitigate the deficiencies of both presidential-parliamentary and parliamentary-presidential rule, with the judicial system as the Achilles heel in both orders, but also prevent the "long-suffering constitution" from being further instrumentalized. In order to break up with constitutional volatility and overall legal uncertainty, and to overcome the gaps in socio-political order in Ukraine, it is not only the presidency that should be transformed and converted into an accountable power institution, but also the system as a whole should be reloaded to become a more sustainable model of governance. The experience of transition societies and the findings of extensive research exemplify that it is not semi-presidentialism, in any of its forms, that is contributing to a greater sustainability and democratic development. On the contrary, the theory and practice of transitional democracy demonstrate that it is a genuinely parliament-dominated rule up to a classical parliamentary mode of government, which contribute to such an end. Against this backdrop, future transition of Ukraine to a classical parliamentary rule presents indeed a popular (support by the majority of Ukrainian population) and (politically and academically) justified constitutional development. Not only would it stabilize the socio-political relations and domestic political processes, but also would contribute to a more congruent and consistent foreign policy. Tellingly, the socio-economical and regional features that are increasingly instrumentailzed in "the only game in the town", i.e. presidential elections, would become mitigated due to the shift of the core of political attraction to the parliament. The latter would encompass a balanced representation of the Ukrainian population (possibly also in a form of a bicameral institution) and thus prevent "win-lose" stalemates produced by presidential elections and the subsequent president-dominated rule. Moreover, constitutional stability and - hardly experienced before - security would immensely contribute to the advancement of Ukraine's foreign policy agen$\mathrm{da}$, including first and foremost its current priority in pursuing economic integra- 
tion and establishing viable political association with the European Union. After all, a meaningful and comprehensive constitutional transition - and not a partial one which has always been pursued in Ukraine before - shall eventually break up the vicious circle of "revolution-constitution-revolution" and prevent revolutionary constitutionalism from remaining the main form of constitutional process in Ukraine in the near future. Only evolutionary constitutionalism, a genuine revolution in constitutional affairs, would help Ukraine out of the perennial constitutional instability and insecurity that have been fraught by now with both social and political vulnerability as well as state's own (internal and external) insecurity. The perils of this insecurity have been eloquently demonstrated by the most severe three-month domestic crisis of 2013-14, the illegitimate but nonetheless succeeded secession of Crimea and the allegedly separatist gamblings in the country's east.

\section{References:}

Association Agreement between the European Union and the European Atomic Energy Community and Their Member States, of the One Part, and Ukraine, of the Other Part. Retrieved from: http://eeas.europa.eu/ukraine/assoagreement/assoagreement-2013_en.htm.

Boban, D. (2007). "Minimalist" Concepts of Semi-Presidentialism: Are Ukraine and Slovenia Semi-Presidential States? Politička Misao, XLIV(5), 155-177.

Borisov, S. (2010). Yanukovych Pledges "Democratic Constitutional Transit". Retrieved from: http://rt.com/politics/ukraine-constitution-reform-yanukovich/.

Chaban, N., Vernygora, V. (2010). Ukraine's Constitutional "Saga": Ukrainian Media Reflections of the Constitutional Process. TRAMES Journal of the Humanities and Social Sciences, 14(3), 227-249.

Christensen, R. K., Rakhimkulov, E. R., Wise, C. R. (2005). The Ukrainian Orange Revolution Brought More Than a New President: What Kind of Democracy Will the Institutional Changes Bring?. Communist and Post-Communist Studies, 38, 207-230.

D’Anieri, P. (2007). Understanding Ukrainian Politics: Power, Politics, and Institutional Design. New York and London: M. E. Sharpe.

Draft opinion on the Constitutional Situation in Ukraine. Opinion No. 599/2010 from 20 December 2010. (2010). Retrieved from: http://www.venice.coe.int/webforms/documents/default.aspx?pdffile=CDL(2010)126-e.

Elgie, R. (ed.). (1999). Semi-Presidentialism in Europe. Oxford: Oxford University Press.

Elkins, Z., Ginsburg, T., Melton, J. (2009). The Endurance of National Constitutions. Cambridge: Cambridge University Press.

Filipenko, A. (2011). The Long-Suffering Constitution. Statutes and Decisions: The Laws of the USSR and Its Successor States, 46(2), 74-79.

Kirsch, I. (2014). Ukraine Needs a '2004 plus' Constitution. EurActiv. Retrieved from: http://www.euractiv.com/print/europes-east/ukraine-needs-2004-plus-constitu-analysis-533557. 
Kudelia, S. (2013). If Tomorrow Comes: Power Balance and Time Horizons in Ukraine's Constitutional Politics. Demokratyzatsiya, 21(2), 151-178.

North, D.C., Wallis, J.J., Weingast, B. R. (2009). Violence and Social Orders: A Conceptual Framework for Interpreting Recorded Human History. Cambridge: Cambridge University Press.

Olszański, T.A. (2014). Ukrainian Opposition Divided Over the New Constitution. OSW Analyses. Retrieved from: http://www.osw.waw.pl/print/21777.

Opinion on the Amendments to the Constitution of Ukraine Adopted on 8 December 2004. $C D L-A D(2005) 015$. (2005). Retrieved from: http://www.venice.coe.int/docs/2005/ CDL-AD(2005)015-e.asp.

Protsyk, O. (2003). Troubled Semi-Presidentialism: Stability of the Constitutional System and Cabinet in Ukraine. Europe-Asia Studies, 55(7), 1077-1095.

Rejai, M, Enloe S.H. (1969). Nation-States and State-Nations. International Studies Quarterly, 13(2), 140-158.

Schappele, K. L. (2003). Aspirational and Aversive Constitutionalism: The Case for Studying Cross-Constitutional Influence Through Negative Models. I.CON, 1(2), 296-324.

Stepan, A., Linz, J.J., Yadav, J. (2011). Crafting State-Nations: India and Other Multinational Democracies. Baltimore: The John Hopkins University Press.

Tyushka, A. (2014). A Liberationist Constitution? Maidan's Revolutionary Agenda and Challenges for Constitutional Reform in Ukraine. European View, 13(1), 21-28.

Tyushka, A. (2015). Association Through Approximation: Procedural Law and Politics of Legislative and Regulatory Approximation in the EU-Ukraine Association Agreement. Baltic Journal of European Studies, 15(1), 56-72.

Zelinska, O. (2015). Who were the Protestors and What did They Want? Demokratizatsiya, 23(4), 379-400.

Бєлов, А.М. (2013). Конституціоналізм в Україні в умовах єАиного європейського Аемократичного простору. Порівняльно-політичне право, 3(1), 92-93.

Войтенко, Ю. (2014). Зміни до Конституції від політичної партії УААР: політико-правовий аналіз. Retrieved from: http://blogs.ipress.ua/blogs/zminy_do_konstytutsii_vid_politychnoi_partii_udar_politykopravovyy_analiz_47073.html.

Волошин, Ю.О. (2010). Конституційно-правове забезпечення європейськоӥміждержавної інтеграчї: Теоретико-методологічні аспекти. Київ: Аогос.

Аобродумов, П.О. (2009). Конституціоналізм і політична еліта України: методологічні підходи. Правоввй вісник Української Академї̈ Банківської Справи, 1(2), 23-27.

Єзеров, А. (2011). Конституционная безопасность с позиций конфликтологического подхода. Актуальні проблеми держави і права, 57(10), 76-84.

Єзеров, А. (2013). Конституційна безпеа як скмадник національної безпеки України. Стратегічні Пріоритети, 2(27), 120-126.

Закон України "Про відновлення дії окремих положень Конституції України" No. 742-VII of 21 February 2014. (2014). Retrieved from: http://zakon3.rada.gov.ua/laws/ show/742-18.

Закон України "Про внесення змін до Конститущії України щодо проведення чергових виборів народних депутатів Украӥни, Президента Украӥни, депутатів Верховної 
Ради Автономної Республіки Крим, місцевих рад та сільських, селищних, міських голів" No. 2952-VI of 1 February 2011. Retrieved from: http://zakon3.rada.gov.ua/ laws/show/2952-17.

Закон України "Про внесення змін до статті 98 Конституиї України” No. 586-VII of 19 September 2013. Retrieved from:http://zakon3.rada.gov.ua/laws/show/586-18.

Колодій, А. (2014). Феномен Майдану в контексті пошукумоделі врядування в Украйні. Retrieved from: http://political-studies.com/?p=1039.

Кравчук, А.М. (2014). Аеякі пропозичї щодо подолання політичноӥ кризи в Україні. Українська Правда Блоги. Retrieved from: http://blogs.pravda.com.ua/authors/ kravchuk/52fb82f687dce/.

Мацієвський, Юрій. (2011). Інволюція конституціоналізму і квазі-авторитарний режим в Україні. Вибора та демократія, 3, 49-56.

Мацієвський, Ю. (2015). Інституційна пастка для Украӥни: проблема політичного виживання еліти в слабкій державі. Retrieved from: http://zaxid.net/news/showNews. do?institutsiyna_pastka_dlya_ukrayini\&objectId=1362175.

Найєм, М. (2014). Зміни до Конституції України запропоновані Батьківщиною і УААРом. Українська Проавда. Retrieved from: http://blogs.pravda.com.ua/authors/ nayem/52f7fbcad0dce/.

"Начіональна Конститучія (Проект ВО “Свобода")". (2007). Retrieved from: httр:// www.svoboda.org.ua/ pro_partiyu/prohrama/konstytutsiya/.

Речицький, В. (2015). Український конституційний процес у 2014 році. Часопис “Критика", XVIII(11-12), 18-27.

Розумний, М. (2013). Конституційний процес: Нова політична модель Аля України. Biчe, 23. Retrieved from: http://www.viche.info/journal/3983/.

Савчин, М.В. (2009). Конституціоналізм і природа конституцї. Ужгород: $\Lambda$ іра.

Фісун, О.А. (2011). Респубціка заради спікьного майбутнього: Аимеми українського конституційного транзиту. Вісник ХНУім. Каразіна, Серія "Питання Політоло2ii”, 949, 45-52. 